\title{
Translation, Retranslation and Recreation in the Literary Field
}

\author{
Maya El Hajj \\ Notre Dame University- Louaize, Beirut, Lebanon
}

\begin{abstract}
Abstrac - Ameen Fares Rihani rewrote a few of his Arabic poems, such as "I am the East" and "New York" in English, to enable American and Arab readers to understand the poems within their cultural settings, to promote the Eastern culture in the West, and to introduce the West to the Easterners. This paper argues that in his translations of his own poetry, Rihani was a recreator rather than a translator. A comparative analysis of Rihani's rewritten poems in English and the translations made by other translators of the same poems will prove that the author-translator's choice of terms along with their cultural backgrounds, deep meanings and etymologies reveal his deep understanding of the source and target cultures, the Eastern and the Western ones. The study further analyzes Rihani's literary recreations or in other terms transcreations and examines as well the other translators' rendering of the same works. Comparative study shows how poetry transcends cultural barriers and understands the linguistic and cultural spirit of the target language, thereby attempts to bridge the civilization and cultural gaps between the East and the West.
\end{abstract}

Index Terms-Ameen Rihani, translator, retranslation, Eastern and Western cultures, translation studies, recreation, transcreation

\section{INTRODUCTION}

Ameen Fares Rihani had the privilege of living in his home country, Lebanon in the Middle East as well as in the United States of America. His sojourn in the East and the West enabled him to acquire the linguistic and cultural colorings of both worlds. This drove his nephew, Ameen Albert Rihani (2007), to confirm that "few of the ethnic groups, who emigrated to America, as of the second half of the nineteenth century became writers in their mother tongue-Arabic. ... Very few of these emigrants became writers in both languages, their mother tongue, Arabic, and the acquired language of the New World, English. Ameen Fares Rihani was the first Arab-American writer to publish a collection of poetry and novel in the English Language" (p.11).

Ameen Fares Rihani lived during a tumultuous period of modern time Lebanon. Mount-Lebanon, the nucleus of today's Lebanon, enjoyed at the time a semi-autonomous status under the Ottoman rule, bestowing confessional communities a legislative right to perpetuate their cultural and educational rights and privileges through the Millet system (Salibi, 1996). Mount-Lebanon had become a cross-cultural platform for dialogue and cultural activities promoted by the Jesuit and Protestant missionaries, which established schools, and higher educational instituions (the Syrian Protestant College or the American University of Beirut in 1866 and the Catholic Saint Joseph University in 1887). Under such conditions, Western and Eastern scholarship has flourished in the region and Rihani's work represented the epitomy of the early Eastern Western dialogue. As a result, Ameen F. Rihani's mission as writer and philosopher was to build a bridge, which would link the cultures of the East and the West. Seeking a better understanding of his works in the East and the West, he rendered some of his works into both languages. Here one may wonder whether in doing this Ameen F. Rihani was a translator or a recreator. Among the works, which Rihani rendered, are two well-known poems: "I am the East" and "New York." In both versions, Arabic and English, Rihani's main purpose was to enable the American and Arab readers to understand the poems within their immediate cultural settings. His aim, I believe, was twofold: to promote the East in Western culture and to introduce the West to Eastern world a much needed attempt at the core of narrowing down existing cultural gaps between the East and the West and militating against the "Clash of Civilizations" (Huntington, 1996). Upon reading the original texts and the translated ones by Rihani and other translators, one wonders whether Rihani was more loyal to the original than the translators were or vice versa. Before attempting to deal with this issue, one must refer to what some translation critics and theorists say about retranslation and the difficulties the translator finds when flavoring the target language with the target cultural mindset without being disloyal to the source language and culture.

This study assesses the role of literary translators and/or recreators with respect to the source text. In addition, it intends to show how Ameen F. Rihani's originality as a recreator/rewriter rather than as a translator of his own poetry transcends the barriers of cultures. It also highlights some terms or expressions that are untranslatable in the target language and seeks to discuss the proper way to deal with such hurdles.

\section{REVIEW OF LITERATURE}


The seminal analytical book of Mohammad Farghal and Ali Almanna (2015) dedicates a full chapter on discussing the cultural considerations and translations which play a major role in the target culture. According to Farghal and Almanna (2015, pp.98-102), "The polar opposition between foreignizing and domestication culture needs to be reconciled in a way that ensures comprehensibility while not compromising cultural elements...". When the translator can strike a balance between playing the role of "insider" and "outsider" properly with respect to two cultures in question; then he will be doing a faithful job". According to Nida (1979 cited in Hatim, 2001), the emphasis in translation is on the relationship between language, culture and society and how some of the pratical insights may be applied in the study of translation (p.18). These critics demonstrate the standard against which I base my argument about Rihani as a recreator rather than a translator. There is a thin line between creativity, creation within the literary field and literary translation in general as our case study. Lierary translation requires a high level of meticulousness. In order to render a literary text faithfully, one has to make sure that the message is rendered at all levels even when some untranslatable items occur or some foreign concepts prevail. The translatability of the structures in linguistics structures would have to be considered even if they were initially untranslatable for human beings (Benjamen, 2012). Thus, as Deane- Cox (2014), in such studies what has to determine our analysis at this level are not solely the structures or simply the applied translation techniques but also values, beliefs, and images in the target culture. Socio-cultural considerations are to be thoroughly examined at this level. Our case study is part of the discourse that attempts to bridge cultural gaps and corollary prejudice and biases fueling antagonism among nations. As a result, it is like moving from Globalization to the Great City with the Universal Spirit as Ameen Albert Rihani (2002) states in his study on Ameen F. Rihani.

\section{METHODOLOGY}

This study employs comparative discourse analysis of literay text of Rihani's poems "I am the East" and "New York and the translations made by other translators of the same poems in English, Arabic, French, and Italian. According to Blommaert and Bulcaen (2000), critical discourse analysts analyze a variety of topics, including political discourse, ideology, racism, etc. This study adopts discourse analysis to analyze intercultural output through literary texts taking " $I$ am the East" and "New York" as a comparative case study. In general, critical discourse analysis offers the possibility of illustrating certain aspects of Translation, Retranslation and Recreation in the Literary Field highlighting difficulties and challenges related to the meticulousness of the renditions of the meanings reflecting differences and uniquess of each culture. Specifically, the study focuses on the cultural differences in the several translations of "I am the East" and "New York" and analyzes how these elements were rendered into the target culture and language in the context of literary translation.

A discourse record was designed to include all information I intended to analyse. In particular, I closely examined several translations or retranslations into the same target languages mainly French and Italian for this same work. I compared the different versions and analyzed them. Finally, I used key words related to Translation Studies in order to provide a solid tool for data gathering in this research endeavor.

\section{Research Questions}

This paper seeks to answer the following research questions:

1- Was Rihani more accurate with respect to the original text than the translators were or vice versa?

2- How does Ameen F. Rihani's originality as a recreator/rewriter rather than as a translator of his own poetry transcend the barriers of cultures?

3- Do some translations'or retranslations' versions have some shortcomings related to their inability to completely understand the linguistic and cultural spirits of the target language?

\section{ANALYSIS}

As a first step, the data I collected from my interviews with the translators or from the archived translations I obtained from the Rihani's museum in Lebanon, furnished the study with the necessary information for answering its research questions. I analyzed the content of the translations I had access to objectively with the concern of creating just like Rihani himself a bridge between the East and the West within the field of translation studies. It is worth introducing at this level the English, French, and Italian translators of "I am the East". Naji Ouejan, Professor of English Literature, translated the poem into English in his English version titled Hymns of the Valleys, of Rihani's Arabic anthology of poems titled "هناف الاودية" that was published in 2002. Oueijan did not refer to Rihani’s English version, written in 1923, as he explained to me during and interview. Two different French versions of the poem by two unknown translators will be analyzed in this paper, I will also refer to an Italian version of the same poem by Francesco Medici, who is a well-known translator and an official member of the International Association for the Study of the Life and Work of Kahlil Gibran, Italianist and Literary Critic, translated many of Gibran's works into Italian including: Lazarus and His Beloved (Lazzaro e il suo amore, 2001), "The Blind" (Il cieco, 2003), The Prophet (Il Profeta, 2005). He also translated into Italian: The Book of Khalid by Ameen Rihani (Il Libro di Khalid, 2014) and the poetry collection Arab Poets of the Diaspora (Poeti arabi della diaspora, 2015), where his translation of "I am the East" is published. 
Rihani starts his poem by referring to the first characteristic of the East, which is Faith through numerous references, one of which is "cornerstone," which comes from a passage from the Holy Bible (Psalm 118, pp.22-23). The stone, which the builders rejected, has become the chief cornerstone, which in Arabic is, "حجر الزاوية", transliterated as hajar 'al-zawija. At this level, a very important connotation is kept in English, Arabic, and Italian with "la pietra angolare," but almost literally rendered in the French version of the unknown freelance translator as "la pierre fondamentale" instead of "pierre angulaire," which made the word lose the spiritual connotation that Rihani intentionally used. In addition to this, there exist many terms that only describe Eastern traditions, thoughts, or customs. I will start my analysis by providing a few examples that confirm the importance of mastering soundly the object of the translation task, taking into account the concept of foreignization and domestication (Venuti, 2008).

In Arabic, Rihani says:

transliterated as such:

(lidhalika tarãni mahniyya lzahri walakinnani kawimurra'yi thabitu ljanan)

The translated English version reads as follows:

Though all you can see is my bent back,

I have a right mind and a brave heart.

In Italian and French the same idea is kept:

Se di me puoi vedere solo la schiena ricurva,

Miei sono il retto pensiero e il cuore saldo. (Italian)

C'est pourquoi tu me vois le dos courbé,

mais j'ai la pensée droite et le coeur solide. (French)

Whereas Rihani in his own rewritten English version of "I am the East" says:

I have been bowed down and I have been free.

Findings

The message is significant here, and Rihani, who is the master of his own piece, knows what to say and how to say it without any restriction at any level. This is a message to the Westerners informing them that the East has been free despite the wars, challenges, difficulties, poverty and all sorts of complications forced on it. It has overcome slavery and thus is liberated. In Arabic, it is the notion of a right mind and a brave heart; yet to the West, it holds a hidden message that none of the translations, though aware of it, are allowed to reveal.

In my opinion, there is no need for the translators to say it differently, since the purpose in this case is to transmit a faithful message. As Peter Newmark states, "The most important task for translators is to narrow the gap between tageteers and sourceres" (1981 p.38). Thus, Newmark's concern is to be faithful to the message of the Source Language. At this level, we can only wonder if the translated versions are communicative or semantic, according to the Newmark theory.

A semantic translation stays within the Source Language culture and focuses on the translation itself as a process. The translation is not fixed and needs to be redone with every new generation as language is permanently modifying, and terms at different stages of history change as well in meaning. In short, a semantic translation shows "an accuracy of reproduction of the significance of the Source Language, whereas the communicative translation shows accuracy of communication of Source Translated message in Target Translation" (Munday, 2007, p.72). Except for a few cases, I contend that the communicative translation was adopted in Rihani's translated versions.

In "New York", Rihani starts his poem briefly stating all the characteristics of New York: "She is the daughter of revolt in the ancient world, the bride of oddity in the New World and the mother of disorder of both." What a revealing image of New York! The selection of terms is quite intelligent in the rewritten Arabic version: "the bride of oddity in the New World” is rendered by عروس التفرّد في العالم القديم, transliterated as ('arus al-tafarrud fil 'alam alkadim). Odd is what is out of the ordinary, and تفرّد transliterated as (tafarrud) is what is completely unique in a positive way. Negativity is more sensed in the English version to reveal a clear sarcastic tone at the beginning of the poem.

Furthermore, when studying this meaningful thought in "I am the East"-

انا جسر الثمس

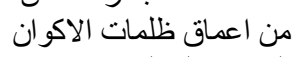

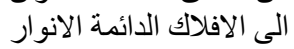

Transliterated as (Ana jisrushamsi min a 'makithulumati l'akwãni 'ilal'aflaki lda'imatil'anwãr)_

one can clearly see the direct link between two opposites: Darkness and Light. The Easterner does not have to cross darkness to reach the light. According to his thoughts and beliefs, this crossing is somewhat bizarre, given that it could not take place without a religious dogma or philosophical principle. Thus, in its presentation, it is an archetype of Eastern thought. To observe the English, French, and Italian translations is telling at this stage.

I am the bridge of the Sun

Suspending from the dark depth of the galaxies

To the ever-lit orbits. (English)

Je suis le pont du soleil

Qui se lève chaque jour de la profondeur des ténèbres des univers

Pour atteindre les sphères éternellement lumineuses. (French) 
Sono il ponte del sole sospeso

Tra le nere profondità delle galassie

E le orbite sempre accese. (Italian)

\section{Whereas Rihani rewrote:}

A million suns have stepped upon my back

Rising from their gulf up to their goal

The Italian version is inspired from the English translation, which conveyed the meaning as smoothly as possible. That's why there is little loss in the meaning. The Italian version offers more clarity than the French one, which is more literal. When Rihani rewrote this part, he added more depth to the meaning with his particular choice of words and style rather than just by sticking to a literal translation.

In addition to the previous examples, here is a cultural example taken from "I am the East”: " (watuzawwiduni Șhamsu liltarhal). One can wonder whether this idea sounds clear to the Western reader. In old times and during Arab voyages, travelers relied on the sun for navigation. Although this might be perceived as a universal concept, the entire idea of the term رحل or (tarhãll or rahala) only exists in our Eastern culture. In addition, the entire image of the sun and travel is an image that takes us back in time to the "provisions" taken by the travelers before traveling. At this level, Rihani sees that the sun is all what he needs to start his trip. This is a typical Eastern concept of the nomadic Eastern individual.

The English translation provides a clever and completely appropriate version: "The sun pushes me to wander." Here, the idea is rendered as if the sun motivates the traveler to continue his journey since no equivalent exists in the Target Language at the semantic level. Therefore, the Eastern characteristic has been lost here for the necessity of comprehension. This substitution in translation is called, according to Vinay and Darbelnet, "adaptation" (2000, pp.8493). The translator, here, has cleverly used it in order to make the idea clear. In French we have the following: "Le soleil me fournit des provisions nécessaires pour mon voyage, quant à la merveille de la vue," a literal translation that does not make much sense to a Westerner and does not reveal the true meaning of the verse. Even though the French expression "fournir des provisions" does exist, it is not, according to my analysis, poetic at all; and in this context, it does not render the meaning properly. The Italian version, "Il sole mi sospinge a vagare tra le visioni dei miei occhi e del mio cuore: Sospingere," gives the idea of wandering which is perfectly used here. What explains the absence of the entire concept of الترحل الرحلة (arrihla or attarahul) in the occidental mentality and society is Rihani's rewriting of this poem in English, totally ignoring this concept.

Another example clearly shows the confusion that is caused by the materialistic mindset of the Westerners and the spiritual mindset of the Easterners:

$$
\text { انّ القافلة، قافلة نفسي، ليتّصل بالجوز إئاء }
$$

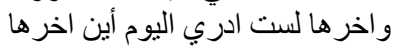

Transliterated as ('innalķãfila ķãfilat nafsi liiațțasil bil jawza' Wa'akhiruha lastu 'adri 'ayna 'ãkhiruhã)

First, let us check the different equivalent to "الجوزاء" (al-jawzã'). According to the English translated version, the equivalent Orion is used: Orion, often referred to as "The Hunter," and is a prominent constellation located on the celestial equator and visible all throughout the world. It is one of the most conspicuous and most recognizable constellations in the night sky. Its name refers to Orion, a hunter in Greek mythology. In French, to "La constellation des Gémaux," the Gemini constellation. The names of the two brightest stars of this constellation, Castor and Pollux, can be found in the Greek mythology. In Italian Orione is taken from the English version, and Rihani himself has preferred to use the word Canopus, which is the brightest star in the southern constellation of Carina and Argo Navis, and the second brightest star in the night-time sky, after Sirius. This is a very clear example of the diversity of the cultures. Only Rihani, who is both Easterner and Westerner, dose not literally use "the Gemini constellation," like most translators have done, because Rihani chose what is commonly used and understood in the East as the Gemini constellation and in the West as Canopus. What is very interesting to mention here is that although the Gemini, Orion, and Canopus constellations, or any of these names, are related to the superior material world, by linking them to the spiritual, Rihani adds a spiritual touch to this materialistic place. In the English rewritten version, however, Rihani used "the leader of my caravan" to make it clearer to the occidental mind. In the translated version, we find the beautiful expression "my soul's pilgrimage" repeated in Italian con "il mio peregrinare infinito (..) il viaggio della mia anima" " قافلة روحي" (ķãfilat rũhii) is then rendered beautifully in the translated English version, applying the modulation procedure in which one of its features is to translate the concrete concept, which is قافلة روحي" (ķãfilat rũhii) with an abstract one "soul's pilgrimage". In French, however, the word "le convoi," omits spirit and thus a loss in the meaning occurs.

In "New York," I would like to mention an interesting neologism, used for the first time by Rihani. In English, the word is "New Yorkalem," which rhymes with "Jerusalem" to establish the paradox of the two cities. In Arabic it is also "نيويوركليم" (Niu iorkalim) to rhyme with "اورشليم" (Orashalim). The intention here, whether in Arabic or in English, bears a hidden meaning when the societal values of these two cities are compared in "The old people enjoy themselves, they do not moan." Jerusalem was once considered as one of the most important cities of the ancient world, whereas 
New York or New Yorkalem, as Rihani named it, is now the center of the New World-purporting and contending dissimilar standards for today's societies than the ones traditional Jerusalem once conveyed.

Rihani provided us with some historical elements in the Arabic version and the way he describes them. For instance,

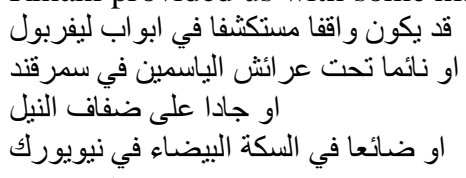

\section{Transliterated as:}

( ķad iakunu waķifan mustakshifan fí 'abwãb līverpũl

Aw na'iman taḥta 'ara'ishil iãsamīn fi samarķand

Aw jadan 'ala dịfafi lnil

Aw ḍã'i 'an fil sikati lbaị̣ã' fi niu iork)

Before I analyze the translations, I would like to highlight the fact that by linking all these places to the Canopus, the author makes each of these places mentioned independent from the other. What is intended here is that people of the East could reach the unreachable and the materialistic location for them is terrestrial and superior. In Arabic, we see مستكثفا في أبواب ليفربول (mustakshifan fi abwãb liverpul) is equal to curiosity of the East to discover Liverpool, the fourth largest city in England and the third largest of the United Kingdom.

نائما تحت عر ائش الياسمين في سمرقندسمرقند (na'iman taḥta 'ara'ish liãsamīn fi samarķand) is an Eastern city in Uzbekistan, lying on the main route to China. Here we see that the poet points out the idea that everything that brings peace and stability is from the East, and the feeling of instability comes from the West.

Here is the English translation:

It may rest with inquisition at the doors of Liverpool

Or it may rest under the jasmine in Samarkand

Or labor at the banks of the Nile River,

Or lost in the white railway in New York;

This describes the psychological state of Rihani: Instability, contradictions, peace, and loss...

Whereas Rihani in his rewritten text says:

He may be packing yet in Samarkand

Or in Benares or Peking;

He may be yawning in the shadow of the Kaaba

Or trudging through the Valley of the Nile;

He may be passing through the gates of Liverpool

Or lagging on the White Way of New York.

This clearly shows that Rihani adds different renowned locations from the East such as Al Kaaba, which has a crucial religious value to the Muslim pilgrims, and also from the West such as Peking, which is a metropolis in Northern China and the capital of the People's Republic of China. Beijing is one of the Four Great Ancient Capitals of China, and Benares, is regarded as a holy city by Buddhists and Jains, and is the holiest place in the world in Hinduism (and center of the Earth in Hindu cosmology). It is one of the oldest continuously inhabited cities in the world and probably the oldest in India. He does so intentionally to introduce the East to the West, thus creating a link between these different cultures by bringing them closer to each other. What is applied here is what Ameen Albert Rihani (2007) states that the creative language of where Arabic and English 'can almost touch,' where East and West can almost sit down and listen to each other and enter into a sincere dialogue of mutual interest, reciprocal attention and common human concern are revealed.

In the French version, we have the following:

Il se peut qu'il découvre aux portes de Liverpool,

Ou bien qu'il dorme sous les plantes de Jasmin à Samarkand,

Ou bien qu'il se tienne, le ton sérieux, aux bords du Nil

Ou qu'il soit perdu sur le chemin blanc à New York.

In the Italian version, we read:

Posso varcare le porte di Liverpool,

riposare sotto il gelsomino a Samarcanda,

arrancare sulle rive del Nilo,

attardarmi sulla White Way a New York

"Varcare" means oversteps or exceeds the limits and "arrancare" to struggle along. This Italian version perfectly renders the intended meaning of the Arabic one and explains Rihani's state of mind. In addition to that, in the middle of the poem Rihani uses the word "صوت" seven times in Arabic. Let us check all the translations especially the equivalent of the term "voice" and the adjectives attributed to it in order to check the interference of the languages. The repetition of the word "voice" in English, French, Italian and Arabic has a strong impact. In the English translation: "I am a voice that rises in retreats, a voice that echoes in the desert, a voice which whispers in your ears, a voice, which waves with peace, a voice which eagerly seeks Mecca and Medina, a voice, which tolls loud on the new podiums, $\underline{\text { a voice, which }}$ 
sings of 'Nirvana' to gods of gold, a voice which praises "Karma" and predestination, a voice, which cheers in the clubs of your country, you son of the West," and in Arabic:

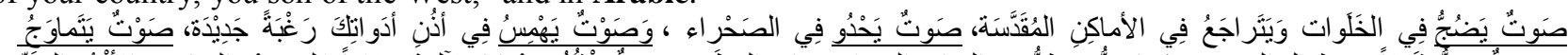

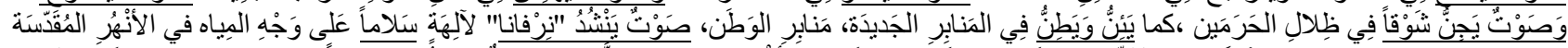

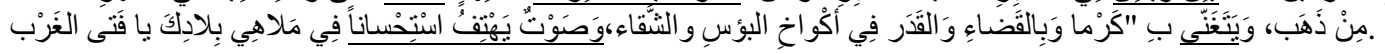

Transliterated as such:

(Sawtun yạ̣juju fil khuluwãt waiataraja 'u fil'amãkin lmuķaddasa, sawtun yaḥdu fi ȘȘaḥra', wasawtun yahmusu fi 'udhuni 'adhwatika raghbatan jadida, sawtun iatamãwaju salãman 'ala wajhi lmiiãh fil 'anhuri lmuķaddasa wa sawtun iajunnu shawķan fi zilãlil ḥaramain, kama ia'innu waiațunnu fil manãbiril jadida, manãbiril wațan, sawtun ianshudu nirvãna li'ãlihatin min dhahab, waiataghanna bikarma wa bilķadã'i wal ķdar fi 'akwãkhi 1 bu'si wal shaqã', wa sawtun yahtifu istiḥsãnan fi malãhi bilãdika ya fata 1 gharb.)

\section{In Italian the text reads as follows:}

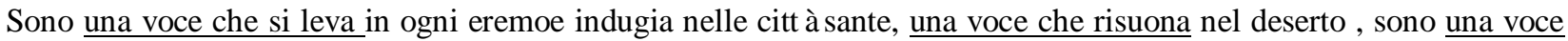

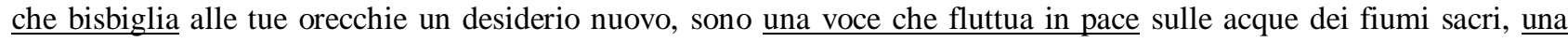
voce trepidante che cerca la Mecca e Medina, sono una voce che riecheggia forte da ogni nuovo podio, sono una voce che canta il nirvana a divinità ricoperte d'oro, e predica il karma e la predestinazione. Figlio dell'Occidente, Io sono una voce che applaude nei club del tuo Paese.

\section{In French, it reads:}

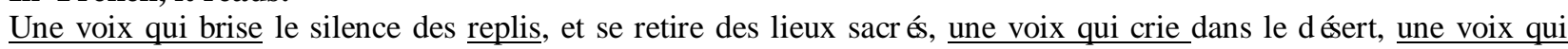
chuchote à l'oreille des vos instruments à travers un désir nouveau, une voix qui ondule à la surface desrivières eaux saintes, une une voix qui désire ardemment à l'ombre des (deux) Mosquées sacrées de la Mecque et de Médine, elle gémit et résonne sur les nouvelles tribunes, celles de la patrie, une voix qui adjure Nirvana au nom de Dieux en or et chante Karma et le destin au fond des huttes de la misère et du malheur, une voix qui crie approbation dans les lieux de distraction, là-bas, chez vous, fils de l'Occident.

The word "voice" is used several times in Arabic to describe the voice of East in the holy places, the voice that badly misses Mecca and Medina, in an attempt to introduce these Eastern places to the West; the voice that praises Karma refers to a fundamental doctrine in Buddhism and the voice that sings Nirvana, refers to the state of enlightenment achieved by the Buddhists.

Rihani's text is filled with Eastern concepts and ideologies that he introduces to the West. This same voice cheering in the clubs of the West is an attempt to describe the type of life in the Western countries. For the Arab people, it is enough to mention "الحرمين" (al-ḥaramain) to know that he is talking about "Mecca and Al-Medina," but for Westerners, it is necessary to mention the names and to explain them; and here is the adaptation process. Even in Rihani's own version, he used Mecca and Medina, explaining that these are two religious cities in Saudi Arabia. He also explains the meaning of the two words "Karma" and "Nirvana." It is important to note an untranslatable item at this level. In Arabic, Rihani uses the word "بحدو في الصحر اء" (yahdu fi ȘȘahra'). This concept is an Eastern one. It is the image of the Arab, the sound emitted during his long trip... The beautiful clever English and Italian correspondent, "I am a voice that echoes in the desert," "il mio voce che risuona nel deserto." According to the French translated version, it is a voice that shouts in the desert. In addition to that, all the translations end the text as Rihani does in Arabic with the idea of the voice that cheers in the clubs of the West. I think, Rihani wanted it to be more meaningful, so he added the following typical Western concept in his recreation of the poem:

A voice that hails in music halls your latest star,

Or argues in your cafes and your clubs,

Over a glass of absinthe or gin-phiz,

About the League of Nations or about

The theory of relativity.

A voice of strange discordances and stranger harmonies:

A voice that echoes in the temples as my many headed Truth,

As well as in the palaces of learning in your land:

A voice that feeds the tumult of my pious moods, the din of my devotion,

And fills with loving silence all the solitary spaces of my shrine-decked hills;

A voice that whispers in the ear of your machines

The new desire, the will to understand

The reason and the purpose of their power;

A voice that cries upon the languid waves of sacred rivers

And from the holy Kaaba over the bone-strewn hills of sacrifice,

As well as from the public tribunes newly-nailed;

A voice that sighs Nirvana

To grotesque idols with big turquoise eyes,

And Karma in the fetid holes of misery and crime;

A voice that hails in music halls your latest star, 
Or argues in your cafes and your clubs,

Over a glass of absinthe or gin-phiz,

About the League of Nations or about

The theory of relativity.

And who other than Rihani knows more about these particularities of the West? He renders the image of the typical daily behavior of Westerners, who spend time entertaining themselves through singing, dancing, drinking, and even chatting about certain activities such as sports. Moreover, an important aspect to mention is that after Rihani had written "I am the East," which was published in Al-Ahram Newspaper in its entirety in 1922, he removed parts of it and did not publish them later. What is interesting to note here is the shocking way he decided to end the poem in Arabic, especially his last version:

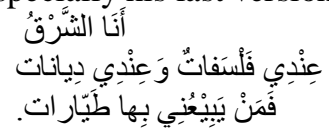

\section{Transliterated as:}

(ana ȘȘharqu

'indī falsafãtun wa 'indi diiãnã

faman yabī uni bihã țaiiãrãt)

I am the East:

Philosophies and creeds, my hankers cry,

Philosophies and creeds for airplanes!

His rewritten version in English continues while his Arabic one ends at this point. It is as if, after having long spoken about the spirituality of the East, he wanted to establish a sort of equilibrium between the Spirituality of the East and the materialism of the West to expose what he calls, "The Great City," which would take spirituality from the East and materialism from the West.

The $1^{\text {st }}$ French version reads:

C'est moi l'Orient,

J'ai des philosophies et des religions.

Qui les échange pour des avions?

The $2^{\text {nd }}$ French version reads:

Je suis l'Orient, j'ai des philosophies et j'ai des religions,

qui les échangerait contre des avions?

\section{The Italian one goes as follows:}

Io sono l'Oriente.

Offro filosofie e religioni

in cambio di aeroplani e tecnologia.

\section{Discussion}

At this stage, it is not wrong to assume that Rihani has delivered his message entirely. According to Ameen Albert Rihani, Rihani's (2007) "universal spirit is the one that emerges from the "Asiatic spirit of Poesy and Prophecy, and the European spirit of Art, and the American spirit of invention, an international society," an ideal of an international society or the "Great City." ( p. 14). Neither New York nor the East, are capable with His unique spirituality and peace to be exchanged with aircrafts; they are enough for our poet, who aims far beyond East and West, to achieve his eternal "Great City."

The above-cited examples highlight the philosophical thought of Rihani and strive to interpret his own ideas in the target languages in accordance to them. The translator ought to have viewed the text as being a religious, sacred one, not simply as poetry or other literary genre. Back to our initial claim, Rihani didn't translate the text into English. However, he recreated in accordance with his cultural backgroung and this is the added value and biggest challenge of literary translated texts. As stated in the work of Deane Cox, quoting from Venuti, "to retranslate is to confront anew and more urgently the translator's ethical responsibility to prevent the translating language and culture from effacing the foreigness of the foreign text (2014, p. 14).

The different translations per language of Rihani's work and retranslations sometimes within the same language prove the need of an internalinalization of the message. This goes beyond linguistic, cultural and stylistic studies or analyses.

\section{Concluding remarks}

The comparative analysis of Rihani's rewritten poems in English and the translations made by other translators of the same poems proves that the author-translator's choice of terms along with their cultural backgrounds, deep meanings and etymologies reveal his deep understanding of the source and target cultures, the Eastern and the Western ones.

\section{CONCLUSION}

The above discussion of the various translations and especially Rihani's, proves if anything that he was not simply a translator but rather a recreator whose original choice of terms, expressions and ideas, and lucidity in accurately 
integrating and segregating the East from the West on all sides and fronts places him above the translators of his works. His basic purpose was to provide his Eastern and Western readers with the opportunity to grasp and enjoy his poems that transcend all societal, cultural, and linguistic boundaries to reach an advanced level of what Naji Oueijan, who like Rihani, experienced both the Eastern and Western culture at first hand, called "Transculturalization," "a process engendering a genuine communication and interaction between two different cultures for the main purpose of enriching both without touching the particularities of any"; Oueijan goes on "When full participation, love, understanding, and objectivity are involved in a translation transaction, translated literary works would not only aid in the transculturalization process but also in the cultivation and enrichment of the target cultures" (2005, pp.90-94). Ameen F. Rihani had the privilege of full participation in both cultures, and as the author of his works, he indeed loved and comprehended his art more than any other translator did. More research is needed to shed light on similar cases in the literary field.

\section{APPENDIX}

Here is the original English version rerewritten by Ameen F. Rihani himself:

\section{Am the East}

Ever since I stood a corner stone

Of God's first temple and of Man's first throne;

I have been bowed down and I have been free.

A million suns have stepped upon my back,

Rising from their gulf up to their goal;

But they have paid their fare, and I'm content.

Indeed, my pockets and my hands are full,

Full of the shining gold the sunrise coins

For traveling nations, traveling visions, too.

And I am traveling still;

The leader of my caravan

Is tethered to Canopus, and the last,

I cannot see the last.

He may be packing yet in Samarkand

Or in Benares or Peking;

He may be yawning in the shadow of the Kaaba

Or trudging through the Valley of the Nile;

He may be passing through the gates of Liverpool

Or lagging on the White Way of New York.

But I'm content; for I can see the first

And hear the tinkle of his bell at eve.

Aye, and his messenger at every dawn

Sings out that all is well,

While he unfolds a new white robe

Made for myself

By him who is Tailor to His Majesty the Day.

$* * *$

I am the East:

Wait for me, my Brave Lad, I come.

Be patient or, at least, be calm.

I'm heavy-laden though you cannot see it

With eyes whose habit is to measure cloth

Or estimate alfala fields.

The pack upon my back, were't visible, would stun your sight.

But in my lap and hands and pockets, too,

Are many other things

From the fields and streams and from the mires of life;

Things that would cast away,

If I could do so without losing faith;

Things that I would hide,

If I could do so without losing shame;

Things that to repair-shops I would send,

If modern artisans had eyes, at least,

To compensate for conscience.

But there are things, O Brother of the West, to yield you perfect joy, 
And things to soothe your aching breast,

And things to smite your soul in loving kindness,

And things to fetter both your hands and feet,

Leaving your heart and mind free to perceive

And contemplate the universe.

$* * *$

I am the East:

The ancient night is still my faithful spouse,

And she will be, methinks, unto the end.

But every day a bright-faced virgin comes

Riding upon the golden steed of dawn

To test my sight and strength.

I rise and lo! My limbs rejoice.

I'm young again!

The virgin splendors of the sunrise flow into my inmost soul

And, like the crystal waters of a mountain stream,

Reveal the ever green though bending ferns

Clinging to steadfast rocks,

Which break the ancient calm

And precipitate to silvery cadences of song

The heavy sluggish rhythms of the hymn of resignation.

$* * *$

I am the East:

A phantom, O my Brave Lad of the West,

In the Material pageantry of Time.

But hear you not the phantom's voice?

A voice of strange discordances and stranger harmonies:

A voice that echoes in the temples as my many headed Truth,

As well as in the palaces of learning in your land:

A voice that feeds the tumult of my pious moods, the din of my devotion,

And fills with loving silence all the solitary spaces of my shrine-decked hills;

A voice that whispers in the ear of your machines

The new desire, the will to understand

The reason and the purpose of their power;

A voice that cries upon the languid waves of sacred rivers

And from the holy Kaaba over the bone-strewn hills of sacrifice,

As well as from the public tribunes newly-nailed;

A voice that sighs Nirvana

To grotesque idols with big turquoise eyes,

And Karma in the fetid holes of misery and crime;

A voice that hails in music halls your latest star,

Or argues in your cafes and your clubs,

Over a glass of absinthe or gin-phiz,

About the League of Nations or about

The theory of relativity.

$* * *$

I am the East:

I go out of the world into myself,

And lo!

An olive-eyed Divinity is born,

A red-eyed Madness also comes to life.

They dance together in the Banyan groves of All-or-none,

And round the flaming altars of my dream,

Missing in ecstasy to penetrate,

With wha umm, wha umm wha-a-a!

The realms ineffable of liberation.

And then, into public square to shout

Against the foreign Devil,

Whether he be carrying a Bible or a gun

Or even a pack of merchandise. 
Labbeik, labbeik!

And don't forget the European Devil

Throw him into the sea,

Or plant a bomb around his club,

Or bribe his native cook.

Wha umm, wha umm wha-a-a!

Labbeik, labbeik!

And they vanish clean,

My red-eyed Madness and my green-eyed God.

Into the desert's undiscovered heart,

Chanting the hymn of mental quietude and resignation,

Whose cadences,

Though they embrace and thrill the golden wrists that glisten in the sun,

And hide among the alum leaves,

And sparkle silver coquetry from the Pleiades,

Fall flat upon my ears in this our age,

Especially when I chance to read

In your own journals, O my Babbling Brother,

The news of how your airplanes

Can bomb and fast destroy your mighty navies.

$* * *$

I am the East:

Philosophies and creeds, my hankers cry,

Philosophies and creeds for airplanes!

Unutterably blasphemous?

But I myself cannot now recognize

The voice which is my own;

The voice that thunders in the public squares

And out of sanctums editorial,

I, too, now have a babbling press

As well as in the tribunes on which frown

The green and yellow eyes of my many-headed gods.

But hearken, O my Strong Lad of the West!

Philosophies and creeds are not what you have them be.

Nor are they what you think in my own eyes:

Neither for farming nor for piety intensified,

Neither for making bath tubs for the world

Or weaving sack-cloth for the world are they:

No, no!

Philosophies and creeds are but the eels

Down in the well of life:

Their business is to keep the water pure,

Or free it, at least, of wiggling squirming things.

$* * *$

I am the East:

In me a thousand colors and fuse

And laminate one through the other neath the brush of Time:

The lucent violet of star-nursed visions;

The sable of lost continents of thought;

The bronze-like native buff of ancient madness;

The opaque purple of stupidity upon the throne;

The dazzling black of wills that run a-muck

Unfettered by allegiance, human or divine;

The scarlet of The Orient for the Orientals:

The drab of Young Democracy with a ferule in her hand;

The iridescences of fancy glazed or grained;

The leprous yellow of aged ecstasy;

And, permeating all with variable sheen,

The rich vermillion that flows from passion's urn

And undulates in enigmatic hues; 
Morosities of mum anemones and melting moons;

Around the couch of lust

And over the obscenities barbaric and refined,

That take their gesture from the simian world

And borrow from the dervish or high-priest

The consecrated mantle of devotion.

Yea, the quintessence of all the cycles past

In which the universe was ill distilled,

As well as of the present,

Is in the cup I drink each day, each night,

The cup that brings the vision, although shattered, to my task

And to my sorrows and my joys.

***

I am the East:

In me a thousand voices speak:

They whisper, murmur, sob,

They hiss and cry,

They sing and chant and wail,

They shout aloud in my own heart,

A rhapsody, a psalmody of silence;

A thousand gods!

Unheard, unseen by you, my One-God, Brother of the West.

Gods of the ancient ever fertile night, they are my gods.

Gods of the virgin henna-fingered dawn, they are my gods.

Gods of the glaring vacancies of noon, they are my gods.

Gods of the lagging lotus-laden afternoon, they are my gods.

Gods of the amber-scented mystic twilight, they are my gods.

Gods of the incense-veiled and turbaned dusk, they are my gods.

Gods of the star-crowned silences of eve, they are my gods.

Gods of the musk-filled navel of the midnight, they are my gods.

Gods with fangs and gods with wings,

Gods with thorns upon their brows and gods with eyes of briar and thorn,

Gods that sing of Blood and fire and gods that speak but one word, Peace,

They are all my gods.

I am their temple, sacred and filed,

Their high-priest and their slave.

But I am also free, my One-God Worshipping Brother of the West,

And in my freedom is a little key,

Which I can use at will

To open and to close the door.

\section{REFERENCES}

[1] Benjamen, W. (2012). The Translator's Task. In L.Venuti, The Translation Studies Reader (p.75). London and New York: Routledge Taylor and Francis Group.

[2] Blommaert, J. and Bulcaen, C. (2000). Critical Discourse Analysis. Annual Review of Anthropology, 29, pp. 447-466.

[3] Deane Cox S. (2014). Retranslation Translation Literature and Reinterpretation. UK: Bloomsbury.

[4] Farghal, M \& Almanna, A. (2015). Contextualizing Translation Theories. UK: Cambridge Scholars Publishing.

[5] Huntington, S. (1996). The Clash of Civilizations and the Remaking of World Order. New York, NY: Simon and Schuster.

[6] Medici, F. (2015). Poeti arabi della diaspora, , versi e prose liriche di Kahlil Gibran, Ameen Rihani, Mikhail Naimy, Elia Abu Madi, Bari: Stilo Editrice.

[7] Mossop, B. 2001. Revising and editing for translators. Np: St Jerome Publishing.

[8] Munday, J. (2007). Introducing translation studies. London and New York: Routledge Taylor and Francis Group.

[9] Oueijan, N. (2005). "Transculturalization: The Case of the Qasida," in Folia Translatologica, Vol. 9, ed. Jana Králová. (Prague: FF UK): 89-100.

[10] Rihani, A. A. (2007). Multiculturalism and Arab-American literature. Washington D.C: Platform International.

[11] Rihani, A. F. (1986). Hutaf Ul-Awdiyat. Rihani Printing and Publishing House, Beirut.

[12] Rihani, F. A. (2002). Hymns of the valleys. Trans. N. B. Oueijan. Gorgias Press, New Jersey.

[13] Salibi, K. (1996). The Modern History of Lebanon. UK: Cravavan Books.

[14] Vinay, J. P. and Darbelnet, J. (1958). Comparative stylistics of French and English. Np.: Didier Harrap.

[15] Venuti, L. (2008). The Translator's invisibility: A History of translation. London and NewYork: Routledge Taylor and Francis Group.

[16] Venuti, L. (2008). The Translation Studies Reader. London and NewYork: Routledge Routledge Taylor and Francis. 
[17] Von Goethe, J.W. (2012). Translations. In L.Venuti, The Translation Studies Reader (p.75). London and New York: Routledge Taylor and Francis Group.

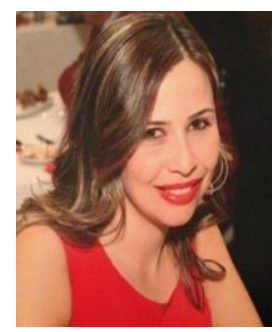

Maya El Hajj is an Assistant Professor at the Faculty of Humanities, Department of English and Translation. She holds a doctorate in Translation Studies from the Holy Spirit University- Kaslik, and a Certification of Competence in Teaching Italian as a foreign language or second language (CEDILS), from the Ca 'Foscari University of Venice, Italy. Her main interest is the effect of culture on languages. Her main teaching area is Translation and Languages, mainly English, French, Arabic and Italian. In addition to her interest in Translation and Teaching, Dr. El Hajj is particularly interested in lexicology-lexicography, a vast field hardly exploited nowadays in the Arab world. Her doctorate dissertation, which is entitled "Etude comparative des dictionnaires bilingues et monolingues", addresses specifically that field. Dr. El Hajj has given lectures and conferences in many academic institutions in Lebanon, England, Greece, France, Georgia and Italy. 